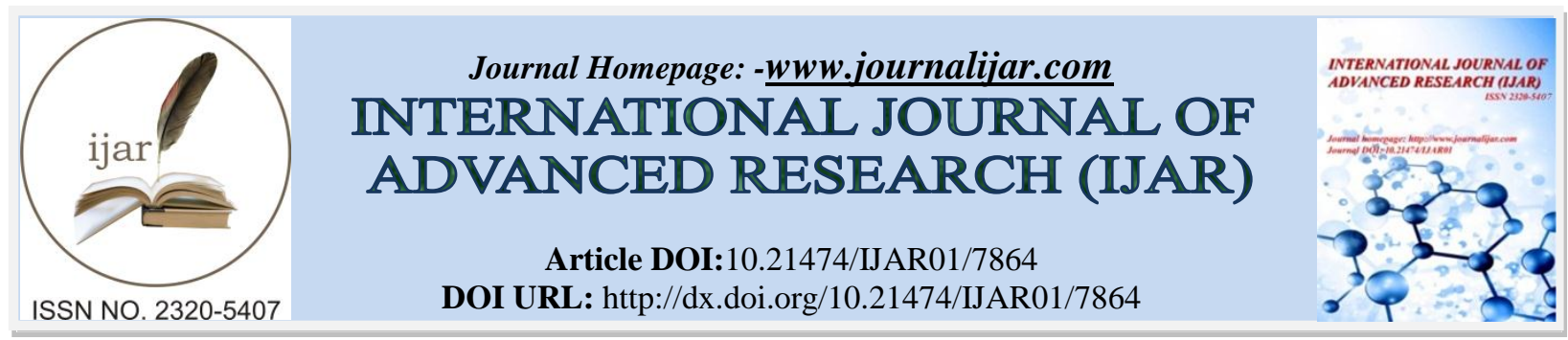

RESEARCH ARTICLE

\title{
CULTURAL CONDITIONS DURING IKSHVAKUS OF VIJAYAPURI.
}

\author{
Balusupati Hari Krishna. \\ Research Scholar Department of History and Archaeology Acharya Nagarjuna University.
}

\section{Manuscript Info}

Manuscript History

Received: 9 August 2018

Final Accepted: 11 September 2018

Published: October 2018

Keywords:-

Andhra, Ikshvaku, Culture, Buddhist.

\begin{abstract}
Male involvement in family planning is one of the strategies that were embraced in the International Conference on Population and Development meeting held in Cairo 1994 to help reduce the increasing population in Africa and elsewhere in the world. This study will investigate the common methods of family planning used currently; knowledge practice and attitude of men toward the use of the family planning methods, and the factors that hinder or encourage men to get involved family planning and hence determine family size.The main aim of this study is to determine the factors affecting male involvement in family planning in Sichilayi sub location. There is a relationship between knowledge level of family planning and uptake by men in Sichirai sub-location. This study adopted the cross sectional research design. Snowball non-probability sampling technique was used in this study. Few respondents from Sichirayi sub-location were identified in Kakamega town, and then they were requested to provide information that will help the data collectors identify more respondents within the town.
\end{abstract}

Copy Right, IJAR, 2018,. All rights reserved.

\section{Introduction:-}

Andhra Desa mainly comprises the present State of Andhra Pradesh and parts of bordering neighbor states of Orissa, Karnataka and Maharashtra. As a political division Andhra Pradesh is known in the contemporary Indian Union as the first linguistic state formed during 1956 as most of the population speak Telugu language This linguistic zone has three subdivisions. On the east and north-east can be seen the wider coastal area with Bay of Bengal and with many a break due to the interspersing Eastern Ghats having different names at different regions like Veligondalu, Palakondalu, Seshachalam, Errammalai, and Nallamalai. This area is called as Coastal Andhra comprising the districts of Srikakulam, Vijayanagar am, Visakhapatnam, West Godavari, East Godavari, Krishna, Guntur, Parkas and Nellore.

The cultural horizon had extended in the prehistoric past with the evidences for Lower Paleolithic cultures at Giddaluru and Nagarjunakonda of Krishna Valley, Middle Paleolithic cultures at Renigunta, Haleakala and the lower valley of Suvarnamukhi. The Upper Paleolithic cultures at the places like Billasurgam, Mucchatla Chitamanu and the Neolithic settlements at the places like Utnoor (Adilabad district), Palavoyi and Virapuram (Kurnool district) were also discovered. The use of copper and iron is found simultaneously at Hulikallu (Anatapur district), a solitary example of such nature in Andhradesa. Many cultural settlements with the use of iron are found at Chinnamaruru (Mahaboobnagar district), Akiripalli and Tenneru (Krishna district), Aduguppa (Anatapur district) Virapuram (Kurnool district) and at many more places of these regions. This cultural fabric had extended over a 
territory generally called Trilingadesa (the land between the three famous Saivite Lingas i.e. Draksharamam, Srisailam and Kalevala), known in some of the earlier inscriptions as Andhra it comprised the three subdivisions of ancient period namely Venginadu8 on the east, Renadu on the South-South-West and Asmara (Assaka of the Buddhist literature; mentioned in Satavahana records as Asaka) on the west.

In this inscription it is clear that Rudradaman defeated Vasisthiputra Pulomavi, the son of Gautamiputra Sri Katakana. At the same time it speaks of some matrimony of the Sakas with the Satavahana prince, Vasishtiputra Katakana, the cousin of Pulomavi. This situation aggravated the political insecurity. Yajnasri Katakana, the last great ruler of the line had shifted himself to the Krishna valley around Dhanyakataka in Andhradesa. He was followed by three rulers of the line namely Chandasri Katakana, Vijaya Katakana and Pulomavi. The record of Chandasri is available in East Godavari District. The record of Pulomavi was found in Macaroni inscription of Bellary District. This record speaks of some administrative divisions like Satavahani hara, Satavahani ratta and the like. It indicates that from the time of Yajnasri much attention was paid to reorganize the Satavahana kingdom. In the entire history of Satavahanas, the place of Hala is significant. He was said to have conquered Ceylon (Srilanka). At the same time his period demarcates the emergence of Sanskrit literature overtaking the Prakrit traditions. This is a development carried out during the period of the Ikshvakus. To be brief, in the period of four centuries rule, the Satavahanas could provide an unbiased position for both the orthodox and heterodox cults and also Prakrit and Sanskrit languages. It is certainly a great achievement, at the same time the excavation of Rock Cut Caves, as at Naneghat, Karle, Bhedsa and Kanheri is another appreciable development, which is very much related to the history of Indian Architecture particularly in the art of Stone Sculpture. Ikshvakus succeeded the Andhra Satavahanas. This dynasty was mentioned in the Purana as Andhras, Andhra Bhrityas and Sriparvateyas too49. Bhritya means servant. The Puranas identify their rule for a hundred years (dvi pancasatam samah). There are four kings of this line namely Sri Chantamula, Vira Purushadatta, Uvula Chantamula and Rudrapurushadatta. These rulers had a recorded rule of 72 years. They ruled in the area between Kolleru Lake and Gundlakamma River. The Ikshvakus were great patrons of Hindu religious cults as well as the Buddhist. Nagarjunakonda, which is also known as 26 Sriparvata along with Srisaila, was their main center of activity. One can see the Stu pas, viharas and temples, all made up of brick, at Nagarjunakonda. There are examples like Pushpabhadrasvami temple, Kartikeya temple and temple for Ashtabhuja Narayana Swami. Impact of the Abhors, who invaded the kingdom of the Ikshvakus cannot be ignored. The Ikshvakus had relations with the rulers of Ujjain50, might be the Sakas, Chutes of Bananas and other families. Ikshvakus donated lakhs of pieces of gold, cows and ploughs (ANENA hiramnyakoti gosata Sahara hala sata Sahara) 51. It might have been an attempt to promote agriculture in the foothill areas of the Nallamalais and in the rocky Palanadu. The Ikshvakus issued their records in both Prakrit and Sanskrit languages. As potentates the Ikshvakus are of little importance. But their patronage to the Hindu and Buddhist cults is very much praiseworthy. Women also came from Impala (Srilanka) both as the teachers and learners and taught of sacred knowledge of the Buddhists52. The Invasions of the Abhors, the claims of Salankayanas and the Pavlovas for political supremacy led to the decay and downfall of the Ikshvaku power.

The Ikshvakus of Sriparvata maintained marriage alliances with the daughters of paternal aunts as known from the inscriptional evidence. On the basis of linguistic study, Caldwell opined that the Sriparvata Andhras were local to the lower Krishna valley.

\section{Review of Literature}

As this tribe had 'Ikshu' (cane sugar) astheirtotemic symbol they have come to be known as Ikshvakus (Hangman Rao, B.S.L., 2003: p.88). The Ikshvakus also maintained patronymics. A closer examination indicates that the Ikshvakus of Vijayapur Truled between 225-300 A.D. Though the Puranas mention as / _ many as seven Sriparvata Andhra kings, the available epigraphical record notifies only 4 of the kings. The first king of the Ikshvaku dynasty is Vasisthiputra SriChamtamula, who ruled between 225-245 A.D., in his 5th regnal year he issued an inscription at Rentala (Sankaranarayana R., 1965-66: El, Vol. XXXVII, pp. 29-36) and -59- in his 8th regnal year he issued an inscription at Kesanapalli. Both the places are located in Xanadu close to \&amp;riparvata-Ndgarjunakonda. In order to expand his empire, he maintained matrimonial relations with 'Purina' and 'Dhanaka' families, who were also

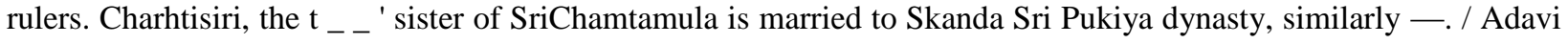
Chamtisiri daughter of SriChamtamula is married to Skanda Sakha of Dhanaka family. T Virapurushadatta, son of SriChamtamula is married to Rudradhara / - Bhattarika, a Saka (Ojanika Maharajah balike) Princess (Hangman Rao, B.S.L., et el, 1998: B-5 Ayaka-pillar, Nagaijunakonda). These matrimonial alliances must have helped SriChamtamula to expand his empire while defending himself from the 'Abhors'. Mahayana wasthe patron deity of Sri Chamtamula, he donated many crores of gold coins, hundreds of thousands of cows and hundreds of thousands 
of ploughs. This indicates that he encouraged cultivation and animal husbandry. He performed Vajapeya, Agnisthoma and Asvamedha sacrifices suggesting his commitment to medic sacrifices. / / 4 Virapurushadatta, son of Srf Chamtamula, ruled for about 20 years as known from the inscriptions. His inscriptions are found at Nagarjunakonda / and Jaggayyapeta. He married Rudradhara Bhattarika, daughter of Saka Rudrasena-II, who was ruling the Jain region. His remaining three queens -60- are the daughters of his paternal aunts. Among them Bapi Sirinika and Charhtisiri daughters of Hammasiri, are only known. However, we do not have the name of the fourth queen, who was the daughter of Charhtisiri. In inscriptions of Virapurashadatta is referred to as 'Mathariputra'. Virapurushadatta had a son by name Ehuvala Chamtamula, and a daughter name Kodabalisiri. Kodabalisiri is married to Sivaskanda Naga Katakana of the Chutukula family of Bananas. During the time of Wrapurushadatta, Sriparvata region is developed as a religious and cultural centre as known from the structural remains at Nagarjunakonda. Ayaka-pillars were added to the Mahachaitya and sculptured panels were fixed as stone encasing to the Mahachaitya on Sriparvata. For the pilgrims coming from 'Impala' a separate vihara complex is created known as 'Sihala Vihara'. During his time, Bodhi fsarma was the treasurer (Raja e Bhahdarika). Bodhi Sarma's sister's daughter by name 'Upasika Bodhisiri' gave many donations to the Buddhistsarigha. She created a 'Chaityagriha' and a 'Chatushala' on 'Chula Dharma Giri' of Nagaijunakonda. These structures are intended for the preachers of Buddha Dharma hailing from Tamraparni, Adhara, Kashmira, China, Tosali, Aparanta, Variga, Vanavasa, Havana and Drami]a etc., (Hangman Rao B.S.L., et al., 1998: pp.152-154). The same Upasika Bodhi Sin, isresponsible for a mandala and many other structures at Kantakosila (Ghantaala). -61- Ehuvala Chamtamula succeeded VIrapurushadatta in about 265 A.D. and ruled till 290 A.D. for a period of 25 years. He issued a copper plate grant discovered at Patagandigudem close to Kallacheruvu village in the Kamavarapukota mandal of West Godavari district, Andhra Pradesh. It must be mentioned here that this is the first copper plate grant in Andhra and the earliest. The grant consisted of 5 plates engraved in Brahmi characters of 3rd4th centuries A.D. The language is Prakrit. The grant mentions about a 'Bikkubhoga' for the monks on his construction of a quadrangular cloister (Chatusthala) near the western gate of the Mahavira at 'Pituhda'. The grant was intended for visitors, residents and monks. The 'ajnapatil was 'Agassi' (Hangman Rao, B.S.L.,et al.,1998: pp.191-193) During his reign there were some political pressures. At Nagarjunakonda a stone inscription of 'Abhira Vasusena' was found. It was dated in the 13th regnal year corresponding to 278 A. D (Sir car, D.C. 1965: pp. 525-526). It is mentioned that 'Siuasepa', the army commander of Vasusena hailing from 'Sarijayapuri' installed the image of4Asthabhujasvami' made of 4Udumbara' wood (var-medi). Scholars like D.C. Sir car opined on this basis that during the time of Ehuvala Chamtamula, the Sriparvata-Nagarjunakonda was under the control of the Abhors for a period of 10 years. Therefore, that the Sakas were friendly with the Ikshvakus appears to be close to the fact. During the time of Ehuvala Chamtamula construction activity gained momentum, the structures indicate equal importance given to Puranic pantheon and Buddhism. She belonged to 'Pushyakandiya' family, and she was the grand child of Mahatalavara Skandagopa and daughter of Mahatalavara Khandapala. A Royal lady from the harem gave a donation to 'Nodagirisuami'. In the Vasusena's inscription cited above it is mentioned that the 'Asthabhujasuama temple was decorated, the well by name Mahanarida was cleared and two tanks were constructed at 'Setagiri' (Nagaijunakonda), and trees were planted. In addition to the above, temples for Navagrahas, Kubera and Kartikeya were constructed during this time as evidenced by the archaeological remains. Either during the last phase of Virapurushadatta or at the beginning of the rule of Ehuvala Chamtamula an Amphitheater was constructed with bricks and encased in stone slabs. Structures of this kind are not known from anywhere in the Andhra Country. 


\section{References:-}

1. Sastry, K.A.N., A History of South India, London, 1958.

2. Rao, G.V., Chapters on the Pre Satavahana and Satavahana Periods in G.Yazdani (Ed.) \&amp; Early History of Deccan, Vol.1, Oxford, 1960.

3. Bhandarkar, R.G., Early History of Deccan, Calcutta, 1962.

4. Rama Rao, M., Satavahana and their Successors, 1971.

5. Hangman Rao, B.S.L., Religion in Andhra, Guntur, 1973 and Buddhist Inscriptions of Andhra Desa, Buddhavihara Trust, Secunderabad, 1998.

6. Subrahmanyam R, Arjuna konda (Ed.)., Vol.1, Archaeological Survey of India, New Delhi, 1975.

7. Himanshu Prabha Ray, Monastery and Guild, Commerce under the Satavahanas, Oxford University Press, Delhi, 1986.

8. Somasundar Rao, The Satavahanas and the Ikshavakus of Jayapura in Early Historic Andhra Pradesh 500 B.C. A.D. 624, Sharma, I.K. (Ed, ), Andhra Pradesh History Congress \&amp; Telugu University, Hyderabad, 2008.

9. Parabrahma Satry, P.V., Society and Economy of the Satavahanas Age in Early Historic Andhra Pradesh 500 B.C. - A.D. 624, Sharma, I. K, (Ed.), Andhra Pradesh History Congress \&amp; Telugu University, Hyderabad, 2008.

10. Balendu Sekharam, K., The Andhra through the Ages, Secunderabad, 1973, pp .148 and 187

11. Guamanian, Buddhist Remains In South India, Cosmo Publications, 1932, p.135.

12. Nila Kantasastry, K.A., A History of South India, (Reprint) Oxford University Press, 1976, p.98. 